\title{
Atlases of geothermal waters and energy resources in Poland
}

\author{
Wojciech Górecki • Anna Sowiżdżał • \\ Marek Hajto • Anna Wachowicz-Pyzik
}

Received: 25 December 2013/Accepted: 27 October 2014/Published online: 19 December 2014

(C) The Author(s) 2014. This article is published with open access at Springerlink.com

\begin{abstract}
The paper presents results of geothermal projects carried out in the last 23 years by the interdisciplinary research team at the AGH University of Science and Technology, in cooperation with numerous scientific institutions, published in the form of geothermal atlases in different parts of Poland. For many years, the Department of Fossil Fuels at the Faculty of Geology, Geophysics and Environmental Protection, AGH University of Science and Technology, has conducted the fundamental research and implementation work, aiming at the selection of optimum areas for utilization of geothermal waters and energy. Over the years, a methodology of estimation of geothermal resources with use of advanced techniques and numerical modeling has been developed. Recapitulation of the studies of the occurrence and utilization of geothermal waters and energy within geological units of the Polish Lowlands, Carpathians and Carpathian Foredeep has been reflected in seven Atlases. The Atlases represent a result of interdisciplinary, constructive cooperation of specialists from various, often remote fields of knowledge, fundamental and technological in nature, including: geologists, geophysicists, hydrogeologists, geochemists, drilling engineers, heat
\end{abstract}

\footnotetext{
W. Górecki · A. Sowiżdżał · M. Hajto ·

A. Wachowicz-Pyzik $(\bowtie)$

Department of Fossil Fuels, Faculty of Geology, Geophysics and

Environmental Protection, AGH University of Science and

Technology, al. A. Mickiewicza 30, 30-059 Kraków, Poland

e-mail: amwachowicz@poczta.fm

W. Górecki

e-mail:wgorecki@agh.edu.pl

A. Sowiżdżał

e-mail: ansow@agh.edu.pl

M. Hajto

e-mail:mhajto@agh.edu.pl
}

engineers, and many other specialists. The Atlases enable the selection of the most promising areas for utilization of geothermal waters and energy in Poland. The best geothermal conditions are predicted in the Polish Lowlands and Podhale region although in many areas of the Carpathians and the Carpathian Foredeep favorable geothermal conditions also occur.

Keywords Geothermal atlases - Geothermal waters . Geothermal resources · Geothermal installations · Poland

\section{Introduction}

Similar to other European countries, Poland has natural sedimentary structural basins filled with geothermal waters of diversified reservoir temperatures, from 20 to $80-90{ }^{\circ} \mathrm{C}$, in some cases even over $100{ }^{\circ} \mathrm{C}$. The country is characterized by significant low-enthalpy geothermal potential, connected mostly with the Mesozoic sediments. Geothermal waters in Poland can be used at first for heating of private houses and industrial buildings, for preparation of warm water, and for therapeutic and recreational purposes. Use of clean geothermal energy is possible and economically feasible in vast areas of Poland.

Use of geothermal water for heating purpose were initiated in Poland in the 1980s. The experimental stage of the first geothermal plant was opened in the Podhale region in 1992. Since that time six district heating plants have been launched (Fig. 1). Total installed geothermal capacity in 2012 was assumed to 101.9 MWth with heat sales of 533.66 TJ. In recent years, a growing interest has been observed in the recreation and balneotherapy sector expressed by seven new centers (two of them received the health resort status) opened in 2006-2012 (Kępińska 
Research areas :
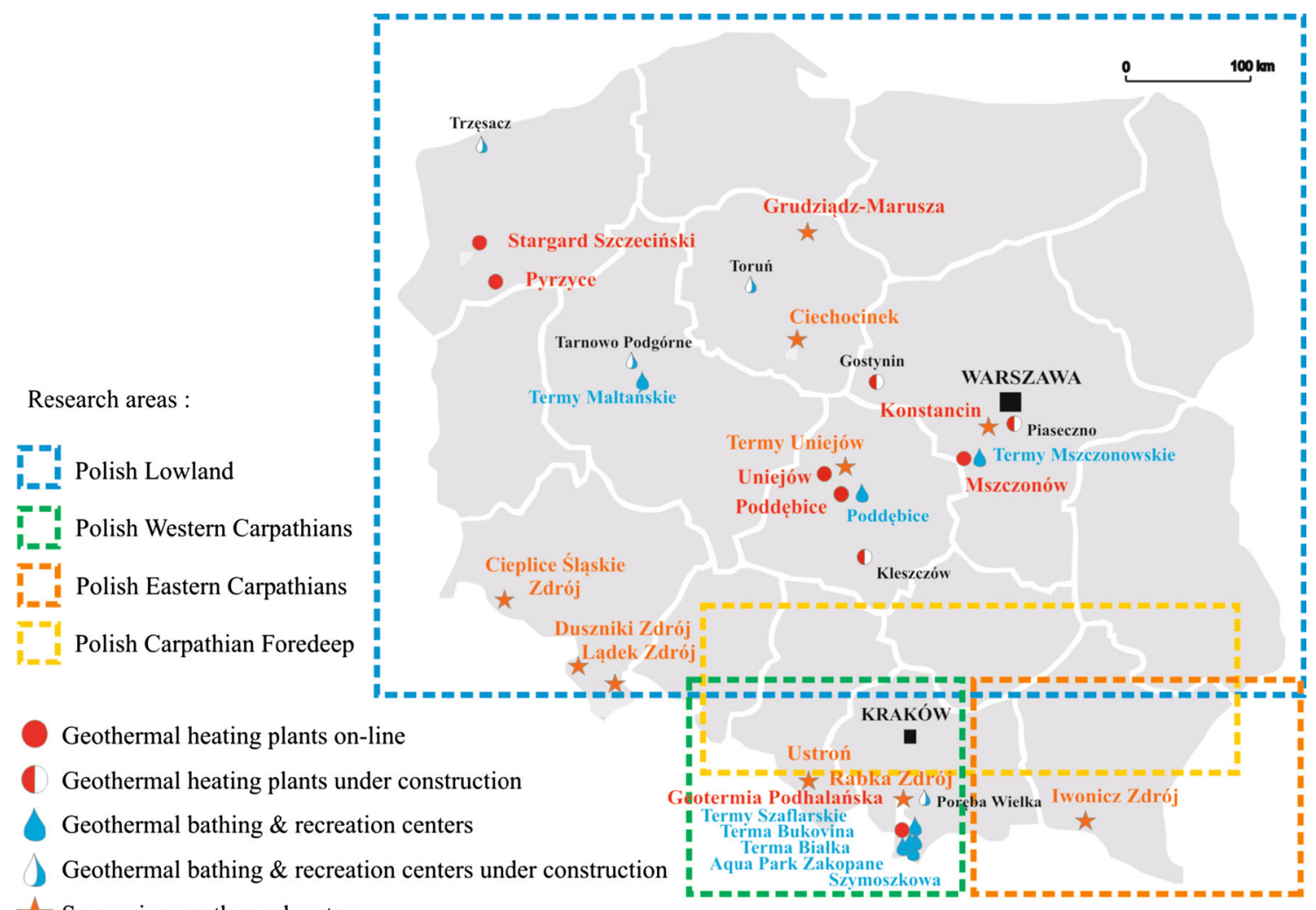

Geothermal heating plants on-line

(1) Geothermal heating plants under construction

Geothermal bathing \& recreation centers

Geothermal bathing \& recreation centers under construction

Spas using geothermal water

Fig. 1 Location of analyzed areas in geothermal atlases as well as location of geothermal installation in Poland

2013). Total installed geothermal capacity of these installations was estimated at $7.45 \mathrm{MWth}$, with heat production equal to $96.1 \mathrm{TJ} / 2012$. New recreational centers are under construction in Kleszczów, Gostynin, Piaseczno, also new installations for bathing and balneotherapy are planned in: Tarnowo Podgórne, Torun, Trzęsacz and Poręba Wielka (Hałaj 2013). Other minor uses comprised semi-technical wood drying and greenhousing, as well as heating up a football playground in Podhale and Uniejów. These applications represented in total ca. 2 MWth, and $6.4 \mathrm{TJ} / 2012$ of heat use (Kępińska 2013). Main parameters of geothermal plants operating in Poland as well as recreation and balneotherapy centers are given in Table 1.

For decades, the AGH University of Science and Technology has conducted scientific research and has issued numerous publications related to the occurrence of geothermal waters in sedimentary basins of Poland. Clean geothermal energy can be used in numerous regions in Poland. Utilization of the geothermal energy enters into the European Union policy which aims at decentralization of energy management and introduction of renewable energy sources wherever it is possible from the point of view of the environment protection and enterprise costs. On the country scale, distributed sources of energy are also essential factors improving the energy security of Poland.

At the Department, geological conditions of the occurrence of geothermal waters are analyzed, together with development of energy resources' calculation methodology and technology required for development of the geothermal resources within geological units of the Polish Lowlands, Carpathians and Carpathian Foredeep. The summary of these studies is represented by the series of geothermal atlases in different parts of Poland (Górecki et al. 1990, 1995, 2006a, b, 2011, 2012, 2013).

The first Atlas published in 1990 focused on analysis of the basic hydrogeological parameters of the main aquifers in the Polish Lowlands. The next one (Górecki et al. 1995) was recapitulation of 5 years of studies aiming assessment of geothermal water and energy resources of the area covering ca. $80 \%$ of Poland. Both of the Atlases were the first regional study under which the geothermal installations such as Mszczonów, Uniejów, Pyrzyce, Stargard Szczeciński (Fig. 1) have been located.

Between 1995 and 2000, the staff from Department of Fossil Fuels analyzed the possibilities of setting up geothermal heating plants in almost 100 towns located in the Polish Lowlands. Studies have contributed to impart dynamism to the utilization of geothermal energy in all of 
Table 1 Main parameters of heat plants (C), recreation (R) and balneotherapy (B) centers in Poland, based on Kępińska (2013) and Górecki et al. (2011)

\begin{tabular}{|c|c|c|c|c|c|c|c|}
\hline \multirow[t]{2}{*}{ Installation } & \multirow[t]{2}{*}{ Type of use } & \multirow{2}{*}{$\begin{array}{l}\text { Maximum capacity } \\
\text { of geothermal water } \\
\left(\mathrm{m}^{3} / \mathrm{h}\right)\end{array}$} & \multirow{2}{*}{$\begin{array}{l}\text { Maximum temperature } \\
\text { of geothermal water } \\
\left({ }^{\circ} \mathrm{C}\right)\end{array}$} & \multicolumn{2}{|c|}{ Capacity installed/estimated } & \multicolumn{2}{|c|}{ Heat use/sale } \\
\hline & & & & $\begin{array}{l}\text { Total } \\
\text { (MWt) }\end{array}$ & $\begin{array}{l}\text { Geothermal } \\
\text { (MWt) }\end{array}$ & $\begin{array}{l}\text { Total } \\
(\mathrm{TJ} / \mathrm{r})\end{array}$ & $\begin{array}{l}\text { Geothermal } \\
(\mathrm{TJ} / \mathrm{r})\end{array}$ \\
\hline \multicolumn{8}{|l|}{ Heat plants } \\
\hline $\begin{array}{l}\text { Geotermia } \\
\text { Podhalańska }\end{array}$ & $\mathrm{C}(+\mathrm{R})$ & 670 & 86 & 80.80 & 40.70 & 512.94 & 362.85 \\
\hline Pyrzyce & $\mathrm{C}$ & 340 & 61 & 48.00 & 14.80 & 100.00 & 60.00 \\
\hline Mszczonów & $\mathrm{C}(+\mathrm{R})$ & 60 & 41 & 112.00 & 3.70 & 33.02 & 11.84 \\
\hline Uniejów & $\mathrm{C}(+\mathrm{R})$ & 120 & 68 & 5.00 & 3.20 & 19.625 & 15.97 \\
\hline Stargard Szczeciński & $\mathrm{C}$ & 100 & 78 & 12.60 & 12.60 & 91.00 & 91.00 \\
\hline Poddębice & $\mathrm{C}$ & 116 & 71 & 3.80 & 3.80 & ND & ND \\
\hline \multicolumn{8}{|c|}{ Recreation and balneotherapy centers } \\
\hline Szymoszkowa & $\mathrm{R}+\mathrm{C}$ & 80 & 27 & 0.30 & 0.30 & 3.00 & 3.00 \\
\hline Terma Bukovina & $\mathrm{R} / \mathrm{B}+\mathrm{C}$ & 40 & 64.5 & 1.35 & 0.35 & 11.00 & 11.00 \\
\hline Terma Białka & $\mathrm{R} / \mathrm{B}+\mathrm{C}$ & 32 & 74 & 3.16 & 3.16 & 37.60 & 37.60 \\
\hline Termy Uniejów & $\mathrm{R} / \mathrm{B}+\mathrm{C}$ & 30 & 42 & 1.00 & 1.00 & 7.70 & 7.70 \\
\hline Poddębice & $\mathrm{R} / \mathrm{B}$ & $\sim 20$ & $\sim 36-38$ & 0.42 & 0.42 & 6.00 & 6.00 \\
\hline Aqua Park Zakopane & $\mathrm{R}$ & 130 & $36-28$ & 0.23 & 0.23 & 1.80 & 1.80 \\
\hline Termy Szaflary & $\mathrm{R}$ & 25 & 38 & 0.14 & 0.14 & 5.00 & 5.00 \\
\hline Termy Mszczonowskie & $\mathrm{R}$ & 15 & 32 & 1.30 & 1.30 & 2.70 & 2.70 \\
\hline Termy Maltańskie & $\mathrm{R} / \mathrm{B}$ & 38 & $\sim 36-38$ & ND & ND & ND & ND \\
\hline
\end{tabular}

the places where the hydrogeothermal conditions with local heat markets ensure the commercial utilization for that kind of energy.

Some ten of the most promising areas were selected and for them concepts of development of geothermal heat were created (Górecki et al. 2006a, b).

In 2011, an extensive publication connecting with geothermal potential of the Western Carpathian was issued (Górecki et al. 2011). The contents of the Atlas provided full information covering the whole of interdisciplinary problems of geothermal resources of Polish part of the Western Carpathians. In 2012, Geothermal Atlas of Carpathian Foredeep was published (Górecki et al. 2012). This Atlas constitutes a comprehensive and exhausting source of information on the occurrence and production potential of geothermal waters in the Polish part of the Carpathian Foredeep. One year later, results of geothermal research carried out in the Eastern Carpathian were issued (Górecki et al. 2013).

The Atlases present characteristics of geothermal systems, uses of geothermal water and energy (e.g., heat engineering, electric power generation, heat pumps, recreation, therapeutics) in Poland and in the world, degree of their utilization, description of functional geothermal plants in Poland as well as classification and methodology of geothermal energy resources' estimation. It should be emphasized that the studies engaged a large team of authors, which assembled scientists and practitioners from many fields related to geothermal energy.

The Atlases present legal, legislative questions and investment risk assessment. Potential sources of financing of the geothermal projects in Poland were indicated. Legal conditions of exploitation of geothermal water and energy were described, as well as obstacles to the development of entrepreneurship and investment costs.

\section{Methods of data analysis and resources' calculation}

Calculations of geothermal energy resources performed for different parts of Poland were based upon the volumetric model (Muffler and Cataldi 1979) with the application of digital mapping methods. The calculations were made with regard to the classification of resources, in accordance with the McKelvey's diagram. The accessible, static and static-recoverable geothermal energy resources have been distinguished (Haenel 1982; Muffler 1975; Muffler and Cataldi 1979; Sorey et al. 1983). Estimation of geothermal energy reserves in respective categories and indication of areas characterized, in a regional scale, by favorable geothermal conditions required analysis of the basic economical parameter influencing the industrial usefulness of geothermal waters as a source of heat. 
Calculation of the respective types of reserves requires the collection of the hydrogeothermal dataset, its relevant interpretation and construction of a geological model of individual geothermal horizons. Achievement of this objective required the following processes (Hajto and Górecki 2005):

- detailed recognition of occurrence conditions of potential geothermal reservoir,

- estimation of geothermal water and energy resources in prospective water-bearing horizons,

- indication of areas where possibility exists for industrial utilization of geothermal energy.

The distinguished geothermal aquifers were characterized from the point of view of: geological setting (lithology, stratigraphy, tectonics), extent, depth and thickness of the aquifers, water temperature and mineralization, discharge of hydrogeological intakes and distribution of the calculated geothermal resources.

Due to a broad spectrum of considered problems, a large number of collected data and high diversification of datasets, various interpretation methods and techniques were applied supported by database tools and basic statistical data processing procedures. The basic materials originated from interpretation of lithostratigraphic columns, well-log data, thermal and hydrochemical data.

All the data from investigations which were made in over 7,000 wells and hundred kilometers of seismic profiles which are presented in the atlases were previously interpreted and analyzed. Generally, all data can be divided into two sections: the geophysical well logs which were taken from wells drilled for the petroleum industry and archival materials (Fig. 2). Both of them include the geology, hydrogeology, water chemistry, hydrogeological parameters from pumping tests, sampling or well testing.

The Atlases were prepared with the use of the GeoGraphix, Z-MAP Plus integrated system of geological data interpretation (from Landmark Graphics Corporation) and
Petrel E\&P Software Platform (Schlumberger) based upon data collected in the geothermal data bank. Results were presented as text and tables, as well as in graphical form as maps. Results of analytical works were displayed in the form of the following maps:

- map of mean annual temperatures,

- structural maps of the top surfaces of hydrogeothermal aquifers,

- maps of geothermal gradients,

- maps of distribution of subsurface temperatures,

- maps of the TDS of reservoir waters in the top part of hydrogeothermal aquifer,

- maps of density of reservoir waters in the top part of hydrogeothermal aquifer,

- maps of total thickness of particular stratigraphic units,

- maps of percentage of groundwater horizons in stratigraphic column,

- maps of cumulative thickness of groundwater horizons,

- maps of average porosity of reservoir rocks,

- maps of average permeability of reservoir rocks,

- maps of hydraulic conductivity coefficient,

- maps of potential discharge of wells,

- maps of distribution of geothermal resources in respective classes.

To assess the geothermal energy resources in Poland for the specific conditions of geothermal, low enthalpy resources, with the dominance of waters at temperatures below $90{ }^{\circ} \mathrm{C}$, the following categories of geothermal waters and energy are being distinguished:

The accessible geothermal energy resources mean the amount of thermal energy accumulated in the Earth's crust down to $3,000 \mathrm{~m}$ depth or to the top surface of crystalline basement, referred to the mean annual temperature of the Earth's surface and expressed in (J). For areas where geothermal waters of low unit enthalpy occur, the accessible geothermal resources $E_{\text {acc }}$ (expressed as the amount of accumulated heat per area unit) are calculated according to the following formula:

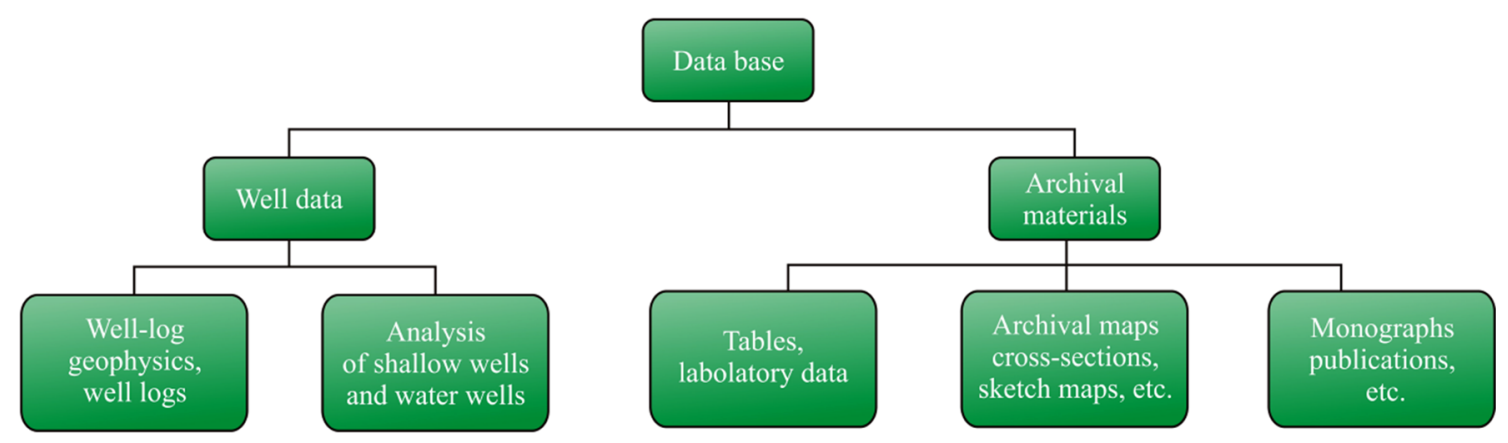

Fig. 2 Methodology of data interpretation 
$E_{\mathrm{acc}}=V_{\mathrm{s}} \cdot \rho_{\mathrm{s}} \cdot c_{\mathrm{s}} \cdot \frac{T_{\mathrm{h}}-T_{\mathrm{o}}}{2 A}\left(\mathrm{~J} / \mathrm{m}^{2}\right)$,

where $V_{\mathrm{s}}$ volume of rocks from the Earth's surface down to $3,000 \mathrm{~m}$ depth $\left(\mathrm{m}^{3}\right) ; r_{\mathrm{s}}$ mean density of rocks down to $3,000 \mathrm{~m}$ depth $\left(\mathrm{kg} / \mathrm{m}^{3}\right)$ (taken as $\left.2,200 \mathrm{~kg} / \mathrm{m}^{3}\right) ; c_{\mathrm{s}}$ mean specific heat of rocks down to $3,000 \mathrm{~m}$ depth $\left(\mathrm{J} / \mathrm{kg}^{\circ} \mathrm{C}\right)$ (taken as $840 \mathrm{~J} / \mathrm{kg}^{\circ} \mathrm{C}$ ); $T_{\mathrm{h}}$ temperature at $3,000 \mathrm{~m}$ depth or at the top surface of crystalline basement $\left({ }^{\circ} \mathrm{C}\right) ; T_{\mathrm{o}}$ mean annual temperature at the Earth's surface $\left({ }^{\circ} \mathrm{C}\right) ; A$ area of calculation block $\left(\mathrm{m}^{2}\right)$.

The static resources of geothermal waters and energy are the amounts of free (gravitational) geothermal water hosted in pores, fractures or caverns of given hydrogeothermal horizon, expressed in $\left(\mathrm{m}^{3}\right)$ or $\left(\mathrm{km}^{3}\right)$, recalculated into the energy units $(J)$. These resources are calculated if the recognition of continuous groundwater reservoirs or horizons is possible in the given area. Based on determined properties of groundwater horizons such as lithology, thickness, porosity and permeability, the identification of producing reservoirs and horizons is possible. The static geothermal resources $E_{\text {stat }}$ are calculated according to the following formula:

$E_{\text {stat }}=A \cdot m_{\mathrm{p}} \cdot\left[(1-\mathrm{pe}) \cdot \rho_{\mathrm{r}} \cdot c_{\mathrm{r}}+p_{\mathrm{e}} \cdot \rho_{\mathrm{w}} \cdot c_{\mathrm{w}}\right](\mathrm{J})$,

where $m_{\mathrm{p}}$ cumulative thickness of groundwater horizons in the reservoir $(\mathrm{m}) ; p_{\mathrm{e}}$ effective porosity $(-) ; T_{\mathrm{s}}$ temperature at the top surface of groundwater reservoir $\left({ }^{\circ} \mathrm{C}\right) ; T_{\mathrm{o}}$ mean annual temperature at the Earth's surface $\left({ }^{\circ} \mathrm{C}\right) ; r_{\mathrm{r}}$ and $r_{\mathrm{w}}$ mean density of rock framework and water, respectively $\left(\mathrm{kg} / \mathrm{m}^{3}\right) ; c_{\mathrm{r}} i c_{\mathrm{w}}$ mean specific heat of rock framework and water, respectively $\left(\mathrm{J} / \mathrm{kg}^{\circ} \mathrm{C}\right) ; A$ area of calculation block $\left(\mathrm{m}^{2}\right)$. It can be concluded from this formula that $E_{\text {stat }}$ is a total amount of heat accumulated in free water and in rock framework, referred to given area of calculation block.

The static-recoverable geothermal waters and energy resources constitute only a part of the static resources diminished by the recovery index $R_{\mathrm{o}}$, expressed in $\left(\mathrm{m}^{3}\right)$ or $\left(\mathrm{km}^{3}\right)$, re-calculated into the energy units $(\mathrm{J})$. The staticrecoverable geothermal waters and energy resources are a part of static resources of given groundwater reservoir or horizon, which can be produced with the given exploitation systems: doublet system (production and injection wells) in which produced geothermal water is injected back to the reservoir after heat recovery and single system (production well only) in which produced geothermal waters are not returned back to the reservoir. It is applied for geothermal reservoirs or their fragments in which fresh or low-TDS waters occur. As in the hydrogeothermal reservoirs of the Polish Lowlands, only high-TDS groundwaters occur; the static-recoverable resources were calculated for doublet system. The recoverable part of geological resources is represented as the recovery index $R_{\mathrm{o}}$ of thermal energy from given reservoir or horizon. For geothermal doublet, this parameter is calculated from the following formula:

$R_{\mathrm{o}}=\frac{A_{\text {cool }}}{A_{\text {tot }}} \cdot \frac{T_{\text {top }}-T_{\text {inj }}}{T_{\text {top }}-T_{\mathrm{o}}}[-]$,

where $A_{\text {cool }}$ cooled area of the doublet $\left(\mathrm{m}^{2}\right) ; A_{\text {tot }}$ total area affected by the doublet $\left(\mathrm{m}^{2}\right) ; T_{\text {top }}$ temperature at the top surface of groundwater horizon $\left({ }^{\circ} \mathrm{C}\right) ; T_{\text {inj }}$ temperature of water injected back to the horizon $\left(=25^{\circ} \mathrm{C}\right) ; T_{\mathrm{o}}$ mean annual temperature at the Earth's surface $\left({ }^{\circ} \mathrm{C}\right)$.

The ratio of cooled area to total area affected by geothermal doublet was taken as empirical constant value based upon long-term experience gained from the operating geothermal installations in the Paris Basin (France). The following, simplified values of this parameter were taken for calculations: for geothermal doublet$1: 3=0.33 ;$ for single well-1:10 $=0.1$. The map of recovery index was constructed by the superposition of two maps: map of temperatures at the top surface of given geothermal horizon and map of mean annual temperatures at the Earth's surface. The map of unit static-recoverable resources for geothermal doublet was constructed with the superposition of two maps: map of recovery index and map of unit static resources, according to the following formula:

$E_{\text {statr }}=E_{\text {stat }} \cdot R_{\mathrm{o}}(\mathrm{J})$,

where $R_{\mathrm{o}}$ recovery index, $E_{\text {stat }}$ static resources (J).

The disposable geothermal waters and energy resources are the amounts of free (gravitational) geothermal water within the horizon or other calculation unit, which can be developed under given conditions but without detailed localization as well as technical and economic specification of an intake, expressed in $\left(\mathrm{m}^{3} /\right.$ day $),\left(\mathrm{m}^{3} /\right.$ year), (J/year) or (TOE/year). Estimation of disposable reserves should be preceded by parametric/economic evaluation of given geothermal reservoir. The disposable reserves constitute a part of assessed static-recoverable resources, the utilization of which would be economically effective. The disposable reserves $E_{\text {disp }}$ were determined as the amount of energy recoverable during 1 year from a geothermal doublet:

$E_{\text {disp }}=Q \cdot\left(T_{\text {top }}-25\right) \cdot \rho_{\mathrm{w}} \cdot c_{\mathrm{w}} \cdot 8,760^{*}(\mathrm{~J} /$ year $)$

where $Q$ rated discharge of potential production well $\left(\mathrm{m}^{3} / \mathrm{h}\right)\left(Q_{\max }=300 \mathrm{~m}^{3} / \mathrm{h}\right) ; T_{\mathrm{s}}$ temperature at the top surface of groundwater horizon $\left({ }^{\circ} \mathrm{C}\right) ; r_{\mathrm{w}}$ water density $(\mathrm{kg} /$ $\left.\mathrm{m}^{3}\right) ; c_{\mathrm{w}}$ water specific heat $\left(\mathrm{J} / \mathrm{kg}^{\circ} \mathrm{C}\right),\left(=4,180 \mathrm{~J} / \mathrm{kg}^{\circ} \mathrm{C}\right) ; *$ coefficient resulting from lifetime of geothermal doublet (1 year $=8,760 \mathrm{~h})$. 


\section{Results}

The most prospective regions for geothermal energy development in Poland are connected with Polish Lowlands and Podhale area (Western Carpathians). Water in these areas is characterized by favorable temperatures (even above $90{ }^{\circ} \mathrm{C}$ ) and relevant value of discharges of wells (to several hundred $\mathrm{m}^{3} / \mathrm{h}$ ). Low discharges of wells are the fundamental problem in the rest of the analyzed regions (Carpathian and Carpathian Foredeep).

The principal resources of geothermal waters in the Polish Lowlands are accumulated in the Mesozoic groundwater horizons. Geothermal waters are accumulated first of all in the Lower Jurassic and Lower Cretaceous formations but significant resources of geothermal energy are accumulated also in the Upper Jurassic, Middle Jurassic, Upper Triassic and Lower Triassic formations.

The Lower Jurassic aquifers are fine- to unequigraniular sands and sandstones of variable thickness, interbedded with semi- or impermeable claystones, sandy claystones, mudstones and sandy mudstones. Permeable rocks constitute 40-80\% of the total thickness of the Liassic sequence. Despite a high vertical variability, horizontal variation and numerous facies changes of the reservoir beds, it may be suggested that underground waters saturating the permeable Lower Jurassic strata form a continuous aquifer. Local discontinuities known from some structural units are caused mostly by fault-block tectonics. The thickness of the Liassic sediments is highly variable, which is a combined effect of the morphology of the pre-Mesozoic basement and of the lithological changes. Aquifers, i.e., reservoir rocks, constitute from 0 to $80 \%$ of the overall thickness. The temperature field changes significantly, from those typical of subsurface waters (outcrops, zones of direct recharge) to $120{ }^{\circ} \mathrm{C}$ in the deep, axial part of the Łódź Trough (central part of Polish Lowlands). The TDS of Lower Jurassic groundwaters is closely related to the depth of occurrence and change from few to over $200 \mathrm{~g} /$ $\mathrm{dm}^{3}$; however, in the whole aquifer values are dominating from 10 to $100 \mathrm{~g} / \mathrm{dm}^{3}$. In most part of Lower Jurassic aquifer, discharges over $100 \mathrm{~m}^{3} / \mathrm{h}$ can be expected.

In comparison with the Lower Jurassic aquifer, the Lower Cretaceous one is less continuous, which is due to tectonic events. Several hydrostructural units can be distinguished, each showing regional differences in lithology of water-bearing horizons and various discontinuities in system of permeable, semipermeable and impermeable beds. Total thickness of Lower Cretaceous formation varies from several to over $400 \mathrm{~m}$ with dominating values between 20 and $200 \mathrm{~m}$. Temperature distribution shows dominance of values from 20 to $40{ }^{\circ} \mathrm{C}$. Only in some areas in central part of Polish Lowlands, temperatures rise to over $50{ }^{\circ} \mathrm{C}$ being related to the axial zones along the central parts of these units. Highest temperatures were observed in the Konin area (over $90{ }^{\circ} \mathrm{C}$ ). Spatial distribution of potential discharges of wells varies from beneath $25 \mathrm{~m}^{3} / \mathrm{h}$ to over $100 \mathrm{~m}^{3} / \mathrm{h}$ (locally even to $200 \mathrm{~m}^{3} / \mathrm{h}$ ).

Geothermal water resources connected with Paleozoic and Mesozoic formations in the Polish Lowlands basin also represent valuable brines that may be used, for example, for production of medicinal and cosmetic salts. For such a purpose, the brines of $\mathrm{Cl}-\mathrm{Na}, \mathrm{Cl}-\mathrm{Ca}$ and $\mathrm{Cl}-\mathrm{Mg}$ type are most suitable. Locally in the area of Polish Lowlands there occur also valuable brines of $\mathrm{SO}_{4}-\mathrm{Na}$ type. The brines from practically all the aquifers of the Polish Lowlands basin contain specific elements of iodine, bromine and iron. Geothermal waters from Cretaceous and Upper Jurassic aquifers are most suitable for recreation, i.e., swimming and bathing, whereas waters from Lower Permian formations maybe used in balneotherapy. The waters from Devonian, Carboniferous, Lower and Upper Triassic, Lower and Middle Jurassic reservoirs may be utilized both for recreation, bathing and balneotherapy. Those brines characterize of high content of bromine, sometimes also potassium and magnesium (Górecki et al. 2006a, b).

In the studied Polish part of the Carpathians, the best reservoir and exploitation properties for geothermal waters utilization occur in the inner Carpathian-Podhale, represented by: favorable reservoir parameters and lithology, usually high yields and regional extent of the aquifer (in both the Polish and Slovak parts) as well as recent recharge and low TDS. Podhale is a region in the western Carpathians where geothermal waters are utilized recently and will be utilized in the future, preferably for heat generation but also for recreation and balneotherapy purposes. The reservoir rocks for geothermal waters are mainly Triassic carbonates, sometimes Jurassic sandstones and carbonates. The most prospective aquifer (subject of exploitation) occurs within the Middle Triassic limestones and dolomites and in overlying Middle Eocene carbonates at the depths of $1-3.7 \mathrm{~km}$. These formations are found over the entire Podhale system, prolonging to the Slovakian territory. Usually, their total thickness is considerable ranging from 100 to $700 \mathrm{~m}$. The average geothermal gradient varies between 1.9 and $2.4{ }^{\circ} \mathrm{C} / 100 \mathrm{~m}$. In some parts of the main aquifer, positive geothermal anomalies were detected: the temperature at the depth of 2-3 km amounts to $80-100{ }^{\circ} \mathrm{C}$ being higher than that resulted from the geothermal gradient (Hajto 2011a). The artesian flow rates from individual wells vary from several to $550 \mathrm{~m}^{3} / \mathrm{h}$. The highest flow rates (up to $270-550 \mathrm{~m}^{3} / \mathrm{h}$ ) were obtained after acidizing treatment of carbonate reservoir rocks.

In the remaining part of the Carpathians, reservoir parameters are much worse. Relatively low geothermal potential was found both in the flysch cover and in the geothermal aquifers of the Mesozoic-Paleozoic basement 
as well. Distribution of the basic petrophysical parameters of rocks in the outer Carpathians shows that improvement of hydrogeological conditions of potential aquifers can be found particularly along the surfaces of overlaps of different flysch tectonic nappes and units. Geothermal waters of flysch aquifers found in existing boreholes are of diagenetic origin. Layers characterized by relatively high porosity and permeability have a rather limited range and small thickness, which have important implications for size and stability of geothermal water intakes.

Within the Miocene and Palaeozoic-Mesozoic basement of the Carpathians, prospective areas for location of potential geothermal water intakes were found within Cenomanian (western Carpathians) and Middle Jurassic aquifers, especially in the marginal zone of Carpathian overthrust. Favorable conditions are confirmed also in some areas of carbonate Devonian-Carboniferous aquifer (e.g., in Ustroń area; Fig. 1). Predicted efficiency of geothermal water intake of flysch and Miocene, Mesozoic and Palaeozoic aquifers in the outer Carpathians was calculated from about 1 to $60 \mathrm{~m}^{3} / \mathrm{h}$-in the western part of the Polish Carpathians, predicted water temperatures are in the range of $30-72{ }^{\circ} \mathrm{C}$, and TDS may vary from about 20 to over $120 \mathrm{~g} / \mathrm{dm}^{3}$.

In some regions of the outer Carpathians, geothermal waters may be used in balneotherapy and recreation, particularly for bathing and swimming facilities. The specific components include iodide and temperature. Considering their high mineralization and temperature, these waters can meet the criteria of balneotherapy and recreation but only after diluting them to the parameters required by the norm (Górecki et al. 2011, 2013).

In Carpathian Foredeep, the aquifers of the Cenomanian, Upper Jurassic, Devonian-Carboniferous and Miocene are most prospective (Sowiżdżał et al. 2012). However, in these aquifers, the most favorable parameters for location of geothermal intakes occur in small areas and depth intervals. The Cenomanian aquifer is an exception, as high discharges (to $250 \mathrm{~m}^{3} / \mathrm{h}$ ) can be expected over the whole area of its occurrence (central part of Carpathian Foredeep). Zones with increased potential discharges of wells are sporadically encountered in the Upper Jurassic (tens $\mathrm{m}^{3} / \mathrm{h}$ ) aquifer and in the Miocene aquifer (above $100 \mathrm{~m}^{3} /$ h). The best hydrogeological and geothermal parameters that indicate the possibility of using the Miocene geothermal water occur in the depth interval 500-1,500 m bsl. The remaining depth intervals seem to reveal low prospective because of low temperatures or weak hydrogeological parameters that determine low discharges of geothermal water intakes. With reference to some areas distinguished principally in the Miocene formations (but also in other aquifers of the Carpathian Foredeep), it should be stressed that sandstones as reservoir rocks occur often in the form of lenses or pinch-outs; their variable thickness can have an adverse effect on stable production parameters in the future perspective. Waters accumulated in the Carboniferous clastic deposits and in the Carboniferous and Devonian carbonate rocks can locally have favorable characteristics (potential discharge of wells max. $50 \mathrm{~m}^{3} / \mathrm{h}$ and temperature even above $200{ }^{\circ} \mathrm{C}$ in deeper part of reservoir). The analyses carried out indicate that the geothermal potential related to utilization of geothermal waters of the Carpathian Foredeep as well as Eastern Carpathians for recreation and/or balneotherapy is much higher than that related to utilization for heating purposes. It results as well from the lower energy demand of geothermal water intakes as from favorable physicochemical parameters of these waters, confirmed by numerous wells drilled especially over vast areas of the Carpathian Foredeep. In some regions, it is possible to develop the groundwater also for heating purposes (space heating, agriculture, agribusiness), usually in association with other sources, including heat pumps (Kępińska et al. 2012).

The estimates of the geothermal resources in the classes of the accessible, static, and static-recoverable resources in different parts of Poland confirm the biggest geothermal potential of the Polish Lowlands (Fig. 3). The lowest potential (expressed by value of disposable geothermal resources) is related to the Eastern Carpathians. Analysis of geological, hydrogeological, and petrophysical/volumetric parameters of the flysch rocks, Miocene deposits and the Mesozoic-Paleozoic basement of the Eastern Carpathians, supplemented by the economic indicator analysis considering the present economic conditions (including the geothermal drilling costs), is indicative of very limited potential for utilization of heat from geothermal waters for heating purposes in the study area. However, hydrogeological parameters of the analyzed geothermal aquifers of the Eastern Carpathians, first of all discharges of intakes and predicted water temperatures, indicate the possibility of building small heating installations with thermal powers ranging from several hundred kilowatts to $5 \mathrm{MWt}$ at the outmost. Geothermal installations with thermal power lower than $2 \mathrm{MWt}$ operate in Poland in a number of objects that utilize geothermal waters for recreational purposes and those of power over $2 \mathrm{MWt}$-in heating installations in Mszczonów (2.7 MWt) and Uniejów (3.2 MWt) where they co-operate with peak load sources of heat: absorption heat pump (Mszczonów) and biomass-fired boilers (Uniejów).

The results of the analyses have been published and discussed on a number of international conferences including World Geothermal Congress 2005, Antalya, Turkey (Hajto and Górecki 2005), European Geothermal Congress 2007 Unterhaching, Germany (Hajto et al. 2007), World Geothermal Congress 2010, Bali, Indonesia (Hajto and Górecki 2010a, b, c; Sowiżdżał 2010) and European 


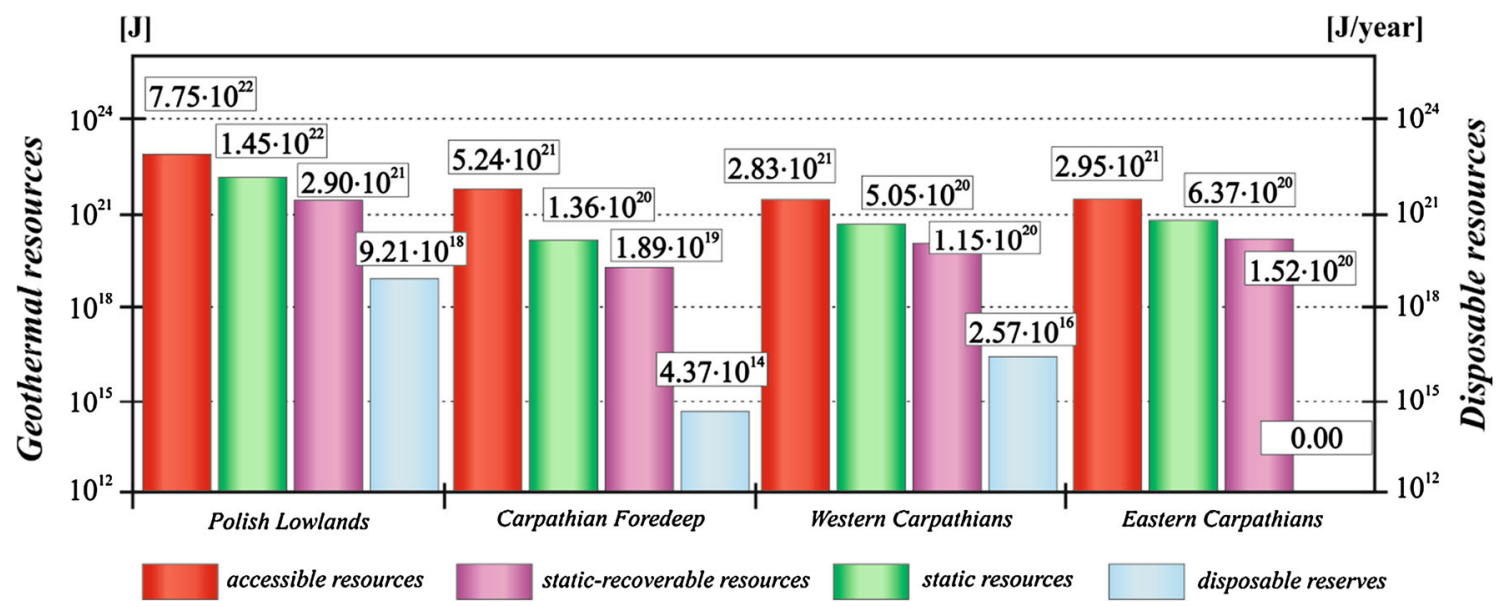

Fig. 3 Distribution of geothermal resources within particular resources classes for different areas of Poland

Geothermal Congress 2013, Pisa, Italy (Górecki et al. 2013) as well as national geothermal congresses which are organized every 2 years by Polish Geothermal Society (e.g., Sowiżdżał and Jasnos 2011; Hajto 2011a, b; Sowiżdżał and Górecki 2013; Hajto 2013).

\section{Conclusions}

The Atlases show that geothermal energy can be commercially utilized in vast areas of Poland. The best geothermal conditions are predicted in the Polish Lowlands and Podhale region although in many areas of the Carpathians and the Carpathian Foredeep favorable geothermal conditions also occur. The scale of this utilization will depend on numerous factors. A very important issue is to break the still existing bad habits and improper standards, which have dominated the state energy policy in the last decades.

The basis for eventual designs of future geothermal installations must be the results of relevant hydrogeological observations made in wells and determination of the character of particular geothermal aquifers including the opinion if the resources will be rechargeable-the feature which would enable the long-lasting, sustainable exploitation under proper parameters. Moreover, directions of utilization of geothermal waters (heat generation, recreation, balneotherapy) should be closely connected with the parameters of water intakes.

Data presented in the Atlases provide full information comprising the whole of interdisciplinary problems of geothermal resources, which can be useful for all those who are active in this field of knowledge. Results of studies and assessment of resources presented in the Atlases enabled the identification of optimum areas for utilization of geothermal waters and energy, where construction of geothermal heating plants is possible. In this case, representatives of the state administration and activists of local governments will find essential information on geothermal waters and the possibility of their utilization in different areas of Poland. The Atlases comprise important information for investors involved in prospecting, exploration and production of warm brines for practical uses.

Acknowledgments This article was inspired by the IAH-CMTW Meeting 2012 held in Budapest, Hungary (August 2012). The authors would like to thank Mr. István Fórizs for the possibility of participation in the conference. The paper has been prepared under the AGH-UST statutory research Grant No. 11.11.140.321.

Open Access This article is distributed under the terms of the Creative Commons Attribution License which permits any use, distribution, and reproduction in any medium, provided the original author(s) and the source are credited.

\section{References}

Górecki W (ed) et al. (1990) Atlas of geothermal resources in the Polish Lowlands

Górecki W (ed) et al. Kuźniak T, Łapinkiewicz AP, Maćkowski T, Strzetelski W, Szklarczyk T (1995) Atlas of geothermal resources in the Polish Lowland. Ed. Towarzystwo Geosynoptyków "Geos"

Górecki W (ed) et al. (2006a) Atlas of geothermal resources of Mesozoic formations in the Polish Lowlands. In: Ministry of environment. Ed. ZSE AGH, Kraków, pp 1-484

Górecki W (ed) et al. (2006b) Atlas of geothermal resources of Paleozoic formations in the Polish Lowlands. In: Ministry of environment. Ed. ZSE AGH, Kraków, pp 1-240

Górecki W (ed) et al. (2011) Atlas of geothermal waters and energy resources in the Western Carpathians. Ed. AGH KSE, Kraków, pp $1-772$

Górecki W (ed) et al. (2012) Geothermal atlas of the Carpathian Foredeep. Ed. AGH KSE, Kraków, pp 1-418

Górecki W (ed) et al. (2013) Geothermal atlas of the eastern Carpathians. Ed. AGH KSE, Kraków, pp 1-791

Górecki W, Sowiżdżał A, Hajto M, Jasnos J (2013) The latest results of geothermal projects in Poland European Geothermal Congress 2013. Pisa, Italy, pp 3-7

Haenel R (1982) Geothermal resource and reserve assessment. Report NLfB, Hannover. Archive No 95, 100 
Hajto M (2011) Potencjał geotermalny w rejonie zewnętrznych Karpat Zachodnich, Technika Poszukiwań Geologicznych : Geotermia, Zrównoważony Rozwój (ISSN: 0304-520X.-2011 R. 50 z. $1-2$ s. $37-49$ )

Hajto M (2011) Charakterystyka termiczna obszaru polskich Karpat Zachodnich. In: Górecki W (red.) i in., 2011-Atlas zasobów wód i energii geotermalnej Karpat Zachodnich. s. pp 281-184

Hajto M (2013) Zasoby oraz możliwości wykorzystania wód geotermalnych w polskiej części Karpat wschodnich, IV Ogólnopolski kongres geotermalny: 30.09-2.10.2013, Zakopane : abstrakty/PSG, GEOTERMIA Podhalańska, Inst. Gospodarki Surowcami Mineralnymi i Energią PAN, KSE, GLOBEnergia

Hajto M, Górecki W (2005) Geological analysis and assessment of geothermal energy resources in selected Devonian, Carboniferous and Permian Reservoirs in the Polish Lowlands-proceedings World Geothermal Congress 2005. Antalya, Turkey, pp 24-29

Hajto M, Górecki W (2010a) Assessment of geothermal water and energy resources of lower Jurassic formations in the NW part of Polish Lowland (Szczecin Trough) proceedings World Geothermal Congress 2010. Bali, Indonesia, pp 25-29

Hajto M, Górecki W (2010b) Atlases of geothermal resources in the Polish Lowlands - the compendium of knowledge for specialists and future investors-proceedings World Geothermal Congress 2010. Bali, Indonesia, pp 25-29

Hajto M, Górecki W (2010c) Geological analysis and assessment of geothermal energy resources in the Polish Lowlands-proceedings World Geothermal Congress 2010. Bali, Indonesia, pp 25-29

Hajto M, Górecki W, Sowiżdżał A (2007) Assessment of geothermal energy resources of Mesozoic and Palaeozoic formations in the Polish Lowlands-proceedings European Geothermal Congress 2007. Unterhaching, Germany

Hałaj E (2013) New geothermal installations for geothermal recreation and therapy in Poland. In: European Geothermal Congress proceedings, Pisa, pp 3-7 (ISBN: 978-2-8052-0226-1, pp 1-5)
Kępińska B, Hajto M, Sowiżdżał A, Kuźniak T (2012) Perspektywy wykorzystania wód geotermalnych w zapadlisku przedkarpackim. In: Górecki W (ed) Geothermal atlas of the Carpathian foredeep. Ed. KSE AGH, Kraków

Kępińska B (2013) Wykorzystanie energii geotermalnej w Polsce 2012-2013, Technika Poszukiwań Geologicznych: Geotermia Zrównoważony Rozwój (ISSN: 0304-520X.-2013z. 1s. 5-24)

Muffler LJP (1975) Geology, hydrology, and geothermal systems. In: Proceedings, second United Nations symposium on the development and use of geothermal resources, vol 1. San Francisco, California, pp 20-29 (Summary of Section II. Washington)

Muffler LJP, Cataldi R (1979) Methods for regional assessment of geothermal resources. Geothermics, pp 7

Sorey ML, Nathenson M, Smith C (1983) Methods for assessing low. Temperature geothermal resources. US Geological Survey, Circural, pp 892

Sowiżdżał A (2010) Assessment of geothermal water and energy resources of Lower Jurassic formations in the NW part of Polish Lowland (Szczecin Trough). In: Proceedings World Geothermal Congress 2010. Bali, Indonesia, pp 25-29

Sowiżdżał A, Górecki W (2013) Możliwości wykorzystania energii geotermalnej w rejonie zapadliska przedkarpackiego-Technika Poszukiwań Geologicznych. Geotermia, Zrównoważony Rozwój (ISSN: 0304-520X.-2013 R. 52 z. 2, s. 59-73)

Sowiżdżał A, Jasnos J (2011) Analiza chemizmu wód podziemnych utworów miocenu w Zapadlisku Przedkarpackim pod kątem właściwości leczniczych Technika Poszukiwań Geologicznych: Geotermia, Zrównoważony Rozwój (ISSN: 0304-520X.—2011 nr 1-2 s. pp 365-376)

Sowiżdżał A, Papiernik B, Hajto M, Machowski G, Jasnos J, Barbacki A (2012) Charakterystyka podstawowych parametrów zbiorników hydrogeotermalnych w zapadlisku przedkarpackim. In: Górecki W (ed) Geothermal atlas of the Carpathian Foredeep. Ed. KSE AGH, Kraków 